\title{
Growth performance of calves fed shoti, wheat and soybean based milk replacers
}

\author{
B. K. Roy*, N. R. Sarker, M. K. Alam \& K. S. Huque \\ Bangladesh Livestock Research Institute, Savar, Dhaka-1341, Bangladesh \\ Corresponding author: biplobkroy@yahoo.com
}

\begin{abstract}
A study was conducted with objectives to determine the comparative growth performance of calves fed shoti, wheat and soybean based milk replacers and their economics. To achieve the objectives, a total of 24 local calves of about 6-10 days of age were selected and divided in four groups; having six (6) calves in each. A limited suckling with feeding whole milk considered as control $\left(\mathrm{T}_{\mathrm{o}}\right)$, suckling along with feeding of wheat, shoti and soybean based milk replacer considered as treatments and denoted as $\mathrm{T}_{1}, \mathrm{~T}_{2}$ and $\mathrm{T}_{3}$, respectively. Results obtained in the present study revealed that, the total DM, OM and CP intake did not differ significantly ( $p>0.05$ ) among the treatment groups. However, calves in $\mathrm{T}_{2}$ group sucked significantly $(\mathrm{p}<0.01)$ higher milk or milk DM compared to milk sucked by calves in $\mathrm{T}_{0}, \mathrm{~T}_{1}$ and $\mathrm{T}_{3}$, respectively. No significant differences ( $>>0.05)$ was observed in average daily weight gain (ADG) of calves among the treatment groups. The feed conversion efficiency (FCR) was relatively better ( $>0.05)$ in calves those fed shoti and soybean based MR compared to calves fed wheat and control diets. The overall levels of both glucose and BUN did not differ significantly $(\mathrm{p}>0.05)$ in calves under different treatment groups. The total cost of per kg wheat $\left(T_{1}\right)$, shoti $\left(T_{2}\right)$ and Soybean $\left(T_{3}\right)$ based MR were Tk. 52.69, Tk. 94.45 and Tk. 51.11, respectively. The processing cost per kg MR was increased Tk. 41.0043.00 in $\mathrm{T}_{2}$ group than that of $\mathrm{T}_{1}$ and $\mathrm{T}_{3}$ groups. The feeding cost per calf per day was reduced $\mathrm{Tk}$. 88.93.00 Tk. 57.87 and Tk. 82.55 in $\mathrm{T}_{1}, \mathrm{~T}_{2}$ and $\mathrm{T}_{3}$, respectively than that of $\mathrm{T}_{0}$ group. Results considering for both FCR and per day feeding cost, it indicates that $\mathrm{T}_{2}$ and $\mathrm{T}_{3}$ diets i.e, shoti and soybean based MR maintained growth of calves compared to wheat based MR and milk fed calves.
\end{abstract}

(Key words: Milk replacer, Shoti, Wheat, Soybean, Daily gain, FCR)

\section{Introduction}

Calves are the future producers of milk and meat for human consumption. Post-natal feeding of calves is very important for better health and growth of calves in commercial as well as smallholder dairy farms. In Bangladesh, dairy cows are mostly non-descript indigenous type. They naturally produced less milk. The demand for milk consumption has been rising faster than its production. The annual milk production in Bangladesh is about 1.89 million metric tons (Tareque and Chowdhury, 2010) and the average growth rate of milk is about $4.21 \%$; its supply daily only $42.0 \mathrm{ml}$ in place of $250 \mathrm{ml}$ per capita requirement of milk (Sarker et al., 2012).

The demand for milk for human consumption restricts availability of milk for pre-ruminant feeding, resulting in underfeeding or starvation with a consequence of stunted growth and mortality (Ranjhan and Pathak, 1979). If suitable substitutes for milk are made available, the nutrition of infant pre-ruminants can be improved and survivability can be increased. In developed countries, alternatives to whole milk feeding to pre-ruminants are formulated using 
by-products of milk processing industry. Such practice is not feasible in the developing countries where milk by-products are scarce and expensive (Khan et al., 2012). Feeding milk replacer to calves is an alternative approach being used in many commercial dairy farms mainly in developed countries to combat this serious problem since long (Plaza and Fernandez, 1994; Sajko et al.,1998 and Mete et al., 2000). The availability of cost effective milk replacer in the market is one of the major hindrance of calves' growth in Bangladesh.

Fresh mother milk feeding is most common at small as well as large dairy farms in Bangladesh. However, the feeding of calves based on a milk replacer may be cheaper than that of feeding whole milk. Milk replacers are the very good source of liquid feed for calves. They are often very economic and in many situations, are more easily adapted to the labour and facility needs of calf raising operations than whole milk (Heinrichs et al., 1995). There are many types or forms of low cost high quality plant protein viz, Soy flour, Soy milk, soy protein concentrate and wheat protein could be used in the formulation of milk replacers. Soy proteins are widely used in milk replacer formulations. Soya protein and wheat protein has an acceptable amino acid profile and is relatively inexpensive compared to most other alternative proteins (Vermeire, 2005). In some countries, soymilk is being used as a novel milk replacer in calf raising facilities (Ghorbani et al., 2007). Soybean meal is an excellent source of vegetable protein (Carpenter 1951). Feeding plant protein based milk replacer (MR) could be an alternative approach of milk feeding keeping the calf healthy and optimum growth. In this connection, from 2010-2011, Bangladesh Livestock Research Institute, Savar, Dhaka has carried out a series of trials under both on-station \& onfarm condition for the development of cost effective Shoti based milk replacer (Roy et al., 2010). It was experienced from the previous studied that shoti always not available and sometime its collection and processing are labor intensive. Therefore, the present study was planned to develop cost effective milk replacers using ingredients with different plant sources and to compare growth performance of calves.

\section{Materials and Methods}

\section{Place of the study}

The present study was conducted at the Cattle farm, Patutia BLRI, Savar, Dhaka-1341. Laboratory works were conducted in the Animal Production Research Division (APRD) and Animal Health Research Division (AHRD), BLRI, Savar, Dhaka-1341. 


\section{Experimental animals and dietary treatments}

A total of 24 local calves (BLRI Cattle Breed-1/Pabna; 20 calves and Red Chittagong Cattle; 4 calves) of about 6-10 days of age were selected and divided in four groups; having six (6) calves in each. The unavailability of Pabna calves during the study period was the main reason to include 4 RCC calves under the research program. However calves were distributed randomly in each treatment group. The calves were reared under group feeding management practices followed in BLRI cattle farm. A limited suckling with feeding whole milk considered as control $\left(\mathrm{T}_{\mathrm{o}}\right)$, suckling along with feeding of wheat, shoti and soybean based milk replacer considered as treatments and denoted as $\mathrm{T}_{1}, \mathrm{~T}_{2}$ and $\mathrm{T}_{3}$ respectively. However, the amount of milk fed by the calves under both groups (control \& treatment) through suckling in the morning and evening were quantified through weighing calves just before and after suckling with the help of a platform digital balance.

\section{Housing and feeding experimental diets}

The calves were housed in an open calf shed, where group-feeding approaches were practiced. The calf shed provided with feed trough for feeding concentrate mixture and green grass and a plastic bucket for feeding water. All calves under control and treatment groups were supplied an iso-nitrogenous diet (CP content 25\%) at a rate of $10 \%$ of their body weight. Calves fed whole milk or milk replacer twice daily at 08:00 and 16:00h using a plastic bottle. Before feeding the calves, fresh milk was collected from bulk collection, filtered to remove extraneous materials and boiled at $100^{\circ} \mathrm{C}$ for 20 minutes. Then, it was cooled to $37{ }^{\circ} \mathrm{C}$ and supplied to the calves. Incase of replacer, the formulated powder was added in hot boiled water maintaining a ratio of 1:7 (milk replacer powder: water), so that the protein content of liquid milk replacer contained similar to milk and cooled down to $37{ }^{\circ} \mathrm{C}$ and then fed to calves. Green grass and concentrate mixture were supplied $a d l i b$ after 2 weeks of age. The experiment was carried out for a period of 50 days.

\section{Measurement of body weight}

The calves were weighed initially just after arrival and weekly thereafter by a platform digital balance. Each calf was weighed in the morning before feeding. The experiment was carried out for a period of 50 days. The total live weight gain was calculated by subtracting the initial weight 
from the final weight taken at the end of the experimental period and the daily weight gain was calculated by dividing the total weight gain by the number of experimental days.

\section{Measurement of intake}

The daily feed intake was measured by subtracting the amount of refusals from the amount of feed offered in the previous day. During feeding trial, the total intake i.e., the actual intake of milk, milk replacer, amount of green grass and concentrate fed by the animals were recorded on daily basis. Incidences of diseases were also observed daily to evaluate the health status of calves.

\section{Chemical analysis of experimental diets}

Representative samples of feed, milk replacers and whole milk were chemically analyzed for dry matter, organic matter, crude protein and crude fiber following the method of AOAC (2005). The acid detergent fibre (ADF) was determined as per Goering and Van Soest (1970). The percent fat and protein content in milk samples were also determined by using a Lactostar (Funke Gerber, model no. 3510-080203).

Table 1. Ingredient composition of milk replacer

\begin{tabular}{|c|c|c|c|c|c|}
\hline \multicolumn{2}{|c|}{ Wheat based MR $\left(\mathrm{T}_{1}\right)$} & \multicolumn{2}{|c|}{ Shoti based MR $\left(T_{2}\right)$} & \multicolumn{2}{|c|}{ Soybean based MR $\left(\mathrm{T}_{3}\right)$} \\
\hline Ingredients & $\%$ & Ingredients & $\%$ & Ingredients & $\%$ \\
\hline Wheat flour & 29 & Shoti powder & 39 & Soy powder & 8 \\
\hline Soymeal & 47 & Soymeal & 50 & Soymeal & 43 \\
\hline Rice flour & 13 & Soybean oil & 9 & Rice flour & 38 \\
\hline Soybean oil & 9 & $\mathrm{DCP}$ & 1 & Soybean oil & 9 \\
\hline DCP & 1 & Salt & 0.5 & $\mathrm{DCP}$ & 1 \\
\hline Salt & 0.5 & Vita-min-Premix & 0.5 & Salt & 0.5 \\
\hline Vita-min-Premix & 0.5 & - & - & Vita-min-Premix & 0.5 \\
\hline Total & 100 & & 100 & & 100 \\
\hline
\end{tabular}

Table 2. Ingredient composition of concentrate mixture

\begin{tabular}{lc}
\hline Ingredients & Percent \\
\hline Broken wheat & 10 \\
Wheat bran & 40 \\
Khesari & 24 \\
Til oil cake & 15 \\
Fishmeal & 3 \\
Soymeal & 5 \\
Salt & 0.5 \\
DCP & 0.5 \\
Oyester cell & 2 \\
\hline Total & $\mathbf{1 0 0}$
\end{tabular}


Table 3. Nutrient composition (\%) of experimental diets fed to calves

\begin{tabular}{lcccccc}
\hline & \multicolumn{5}{c}{ Diets } \\
\cline { 2 - 4 } Nutrients & \multicolumn{3}{c}{ Milk replacer } & Milk & Grass & $\begin{array}{c}\text { Concentrate } \\
\text { mix. }\end{array}$ \\
\cline { 2 - 4 } & $\begin{array}{c}\text { Wheat } \\
\text { based }\left(\mathbf{T}_{\mathbf{1}}\right)\end{array}$ & $\begin{array}{c}\text { Shoti } \\
\text { based }\left(\mathbf{T}_{\mathbf{2}}\right)\end{array}$ & $\begin{array}{c}\text { Soybean } \\
\text { based }\left(\mathbf{T}_{\mathbf{3}}\right)\end{array}$ & & & \\
\hline $\mathrm{DM}$ & 91.77 & 92.86 & 93.03 & 13.01 & 18.87 & 90.78 \\
$\mathrm{OM}$ & 93.95 & 91.61 & 91.66 & 96.70 & 94.21 & 90.69 \\
$\mathrm{CP} /$ protein & 26.49 & 25.50 & 26.63 & 3.38 & 10.70 & 15.25 \\
Fat/EE & 9.61 & 9.58 & 10.12 & 3.78 & 0.12 & 1.30 \\
$\mathrm{ADF}$ & 2.06 & 12.11 & 6.77 & - & 26.33 & 24.70 \\
\hline
\end{tabular}

\section{Blood Collection and Plasma biochemical assay}

The blood samples were collected in the morning prior to feeding of the calves especially from jugular vein into EDTA (20 IU heparin/ml blood) tubes at fortnightly interval. Immediately after sampling, the blood was placed in ice box and taken to laboratory. To separate plasma from the cells, blood samples were centrifuged at $3000 \mathrm{rpm}$ for 15-20 minutes and the plasma were separated and stored in refrigerator $\left(-20{ }^{\circ} \mathrm{C}\right)$ in different aliquots for the analysis of blood urea nitrogen (BUN) and plasma glucose. The blood urea nitrogen and glucose were determined by using a commercial kit (blood urea nitrogen kit \& blood glucose kit) at Serology laboratory under Animal Health Research Division, BLRI, Savar, Dhaka-1341.

\section{Statistical analysis}

Data were subjected to analysis by using analysis of variance (Steel and Torrie, 1980) for a Completely Randomized Design (CRD). Treatment means were compared by using LSD. All the analysis was carried out using SPSS (2002) programme.

\section{Results and Discussion}

\section{Nutrient composition of the experimental diets}

The ingredients and level used for the formulation of milk replacers and concentrate mixture have been presented in Table 1 and 2, respectively and the nutrient compositions of experimental diets shown in Table 3 . The perusal Table 2 indicated that wheat $\left(\mathrm{T}_{1}\right)$, shoti $\left(\mathrm{T}_{2}\right)$ and soybean $\left(\mathrm{T}_{3}\right)$ based milk replacer powder contained 91.77, 92.86 and 93.03 percent DM, respectively. Similarly, the percent OM, CP and Fat (EE) for the respective MR powder were 93.95, 91.61 and 91.66; 26.49, 25.50 and 26.63 and 9.61, 9.58 and 10.12, respectively. Though, the milk replacers 
were iso-nitrogenous, however, after mixing the ingredients it was shown slightly higher in $\mathrm{T}_{1}$ and $\mathrm{T}_{3}$ diets. The whole milk fed and/sucked to calves under all the experimental groups contained 13.01, 96.70, 3.38 and 3.78 percent of DM, OM, protein and fat, respectively. The $\mathrm{DM}, \mathrm{OM}, \mathrm{CP}$ and $\mathrm{EE}$ content in green grass (German grass) and concentrate mixture fed calves under all the groups were 18.87, 90.78; 94.21, 90.69; 10.70, 15.25 and $0.12,1.30$ percent, respectively.

\section{Nutrient intake}

The total DM and OM intake was relatively higher in $\mathrm{T}_{0}$ group compared to calves those fed $\mathrm{T}_{1}$, $\mathrm{T}_{2}$ and $\mathrm{T}_{3}$ diets and no significant difference $(\mathrm{p}>0.05)$ was observed among the treatment groups. Though, the differences among the groups were not significant but relatively higher intake of $\mathrm{DM}$ observed in $\mathrm{T}_{0}$ group. This might be attributed through feeding either from higher grass or concentrate intake. Similarly, the total CP intake in all experimental calves had no effect $(\mathrm{p}>0.05)$ on feeding experimental diets. However, calves in $\mathrm{T}_{2}$ groups sucked significantly ( $\mathrm{p}<0.01$ ) higher amount of milk or milk DM compared to milk sucked by calves in $\mathrm{T}_{0}, \mathrm{~T}_{1}$ and $\mathrm{T}_{3}$, respectively (Table 4).

Table 4. Nutrient intake, average daily gain (ADG) \& feed conversion ratio (FCR) of calves fed experimental diets (Mean \pm SE)

\begin{tabular}{|c|c|c|c|c|c|}
\hline \multirow[t]{2}{*}{ Parameters } & \multicolumn{4}{|c|}{ Experimental diets } & \multirow{2}{*}{$\begin{array}{c}\text { Level of } \\
\text { Sig. }\end{array}$} \\
\hline & $\mathbf{T}_{\mathbf{0}}$ & $\mathbf{T}_{1}$ & $\mathbf{T}_{2}$ & $\mathbf{T}_{3}$ & \\
\hline \multicolumn{6}{|l|}{ Nutrient intake } \\
\hline Fresh Milk sucked (L/d) & $0.79^{\mathrm{b}} \pm 0.01$ & $0.78^{\mathrm{b}} \pm 0.03$ & $1.21^{\mathrm{c}} \pm 0.02$ & $0.87^{\mathrm{a}} \pm 0.03$ & $* *$ \\
\hline DMI Milk sucked $(\mathrm{kg} / \mathrm{d})$ & $0.10^{\mathrm{b}} \pm 0.001$ & $0.10^{\mathrm{b}} \pm 0.005$ & $0.16^{\mathrm{c}} \pm 0.003$ & $0.11^{\mathrm{a}} \pm 0.003$ & $* *$ \\
\hline DMI MR/Milk (kg/d) & $0.26 \pm 0.02$ & $0.21 \pm 0.01$ & $0.22 \pm 0.02$ & $0.26 \pm 0.02$ & NS \\
\hline Total DM intake $(\mathrm{kg} / \mathrm{d})$ & $0.56 \pm 0.04$ & $0.47 \pm 0.05$ & $0.51 \pm 0.05$ & $0.53 \pm 0.04$ & NS \\
\hline Total OM intake $(\mathrm{kg} / \mathrm{d})$ & $0.53 \pm 0.04$ & $0.44 \pm 0.05$ & $0.49 \pm 0.05$ & $0.50 \pm 0.04$ & NS \\
\hline Total CP intake $(\mathrm{kg} / \mathrm{d})$ & $0.12 \pm 0.008$ & $0.10 \pm 0.009$ & $0.11 \pm 0.01$ & $0.12 \pm 0.009$ & NS \\
\hline ADF intake $(\mathrm{kg} / \mathrm{d})$ & $0.05 \pm 0.007$ & $0.04 \pm 0.01$ & $0.06 \pm 0.01$ & $0.06 \pm 0.008$ & NS \\
\hline \multicolumn{6}{|l|}{ Body weight \& FCR } \\
\hline Initial live weight $(\mathrm{kg})$ & $21.87 \pm 2.24$ & $21.00 \pm 1.62$ & $21.62 \pm 1.74$ & $22.02 \pm 3.08$ & NS \\
\hline Final live weight $(\mathrm{kg})$ & $37.50 \pm 5.50$ & $29.75 \pm 2.00$ & $36.52 \pm 4.48$ & $35.30 \pm 2.14$ & NS \\
\hline $\mathrm{ADG}(\mathrm{kg} / \mathrm{d})$ & $0.312 \pm 0.12$ & $0.175 \pm 0.0 .02$ & $0.298 \pm 0.12$ & $0.266 \pm 0.02$ & NS \\
\hline FCR (kg DMI/kg gain) & $2.73 \pm 0.57$ & $2.84 \pm 0.40$ & $1.92 \pm 0.36$ & $2.03 \pm 0.14$ & NS \\
\hline \multicolumn{6}{|l|}{ Blood metabolites } \\
\hline Plasma glucose $(\mathrm{mg} / \mathrm{dl})$ & $49.75 \pm 2.71$ & $43.00 \pm 4.26$ & $40.00 \pm 3.69$ & $44.25 \pm 4.87$ & NS \\
\hline $\begin{array}{l}\text { Blood urea nitrogen } \\
(\mathrm{mg} / \mathrm{dl})\end{array}$ & $17.37 \pm 1.60$ & $23.00 \pm 1.73$ & $19.12 \pm 2.90$ & $18.75 \pm 1.10$ & NS \\
\hline
\end{tabular}




\section{Body weight and feed conversion efficiency}

The initial body weight of calves of $\mathrm{T}_{0}, \mathrm{~T}_{1}, \mathrm{~T}_{2}$ and $\mathrm{T}_{3}$ groups were 21.87 $2.24,21.00 \pm 1.62$, $21.62 \pm 1.74$ and $22.02 \pm 3.08 \mathrm{~kg}$, respectively and the difference among the treatment groups were non-significant $(\mathrm{p}>0.05)$. The similar non-significant effect of feeding experimental diets on final live weight of calves observed under the study. The average final live weight of the corresponding groups were $37.50 \pm 5.50,29.75 \pm 2.00,36.52 \pm 4.48$ and $35.30 \pm 2.14 \mathrm{~kg}$, respectively. The values for average live weight gain of calves were $0.312,0.175,0.298$ and $0.266 \mathrm{~kg} / \mathrm{d}$ in $\mathrm{T}_{0}, \mathrm{~T}_{1}, \mathrm{~T}_{2}$ and $\mathrm{T}_{3}$, respectively. While, no significant difference $(\mathrm{p}<0.05)$ observed in average daily weight gain (ADG) among the treatment groups. The feed conversion efficiency (FCR) was relatively better $(\mathrm{p}>0.05)$ in calves those fed shoti $\left(\mathrm{T}_{2}\right)$ and soybean $\left(\mathrm{T}_{3}\right)$ based MR compared to calves fed wheat and control diets. The values for FCR were 2.73 $\pm 0.57,2.84 \pm 0.40$, $1.92 \pm 0.36$ and $2.03 \pm 0.14$ for $\mathrm{T}_{0}, \mathrm{~T}_{1}, \mathrm{~T}_{2}$ and $\mathrm{T}_{3}$ groups, respectively (Table 4 ). The findings of the present study revealed that average daily gain $(A D G)$ in control group $\left(T_{1}\right)$ was higher than that of milk replacer groups. Almost similar trends was also reported by Roy et al. (2011) who observed higher $(\mathrm{p}>0.05)$ weight gain $(0.36 \mathrm{~kg})$ in calves fed whole milk than calves those fed shoti based MR $(0.33 \mathrm{~kg})$ under on-farm condition. The finding was also in agreement with results reported by Wadud et al. (1985) and Rahman et al. (1988). A non-significant effect in weight gain was also reported by Sajko et al. (1998) which partially supports the present findings.

\section{Blood metabolites}

The overall concentrations (mg/dl) of plasma glucose in $\mathrm{T}_{0}, \mathrm{~T}_{1}, \mathrm{~T}_{2}$, and $\mathrm{T}_{4}$ groups during entire period of experiments were $49.75 \pm 2.71,43.00 \pm 4.26,40.00 \pm 3.69$ and $44.25 \pm 4.87 \mathrm{mg} / \mathrm{dL}$, respectively. Similarly, the concentrations of BUN for the corresponding groups were $17.37 \pm 1.60,23.00 \pm 1.73$, and $19.12 \pm 2.90$ and $18.75 \pm 1.10 \mathrm{mg} / \mathrm{dL}$, respectively. However, the overall levels of both glucose and BUN did not differ significantly $(p>0.05)$ due to treatment effects in calves (Table 4). This finding is inline with results reported by Roy et al. (2011) who did not observe any significant variations of glucose and BUN level in calves fed whole milk and milk replacers based on shoti powder. 


\section{Disease incidence and mortality}

The incidence of diseases and mortality of calves under the study has been presented in Table 5 . It was revealed from the study that the incidence of diarrhea was relatively higher in $T_{1}$ and $T_{2}$ groups as compared to that of groups $\mathrm{T}_{0}$ and $\mathrm{T}_{3}$. Incase of pneumonia, calves in $\mathrm{T}_{1}$ group showed higher incidence than $T_{2}$ and $T_{3}$, while calves in $T_{0}$ group did not affected by pneumonia. No case of blot was appeared in calves fed MR diets except milk fed group where single incidence of blot was appeared. During the entire experimental period, none of the calf had died due to feeding of either whole milk or milk replacers.

Table 5. Disease incidence and mortality of calves fed experimental diets

\begin{tabular}{lcccc}
\hline Items & \multicolumn{4}{c}{ No. of times affected } \\
\cline { 2 - 5 } & $\mathbf{T}_{\mathbf{0}}$ & $\mathbf{T}_{\mathbf{1}}$ & $\mathbf{T}_{\mathbf{2}}$ & $\mathbf{T}_{\mathbf{3}}$ \\
\hline Diarrhea & 6 & 14 & 12 & 8.0 \\
Pneumonia & - & 5 & 2 & 1 \\
Naval ill & 1 & 2 & - & - \\
Blot & 1 & - & - & - \\
Calf mortality & Nil & Nil & Nil & Nil \\
\hline
\end{tabular}

\section{Cost of milk replacer}

The cost involved for preparation of milk replacer was calculated using market price of all individual ingredient. The cost involved per kg Shoti powder (including cost of Shoti collection, processing and grinding), wheat flour, soy powder (including processing cost), soybean meal, rice flour, soybean oil, di-calcium phosphate (DCP), vitamin-premix and common salt were Tk.140.00, Tk. 36.00, Tk. 42.00 Tk. 50.00, Tk. 30.00, Tk. TK. 135.00, Tk. 80.00, Tk. 360.00 and Tk. 20.00, respectively. The total cost of per kg wheat based MR, shoti based MR and Soybean based MR were Tk. 52.69, Tk. 94.45 and Tk. 51.11, respectively (Table 6). 
Table 6. Price of feed ingredients and cost for the preparation of milk replacer

\begin{tabular}{|c|c|c|c|c|c|c|c|}
\hline \multirow[t]{3}{*}{ Ingredients } & \multirow{3}{*}{$\begin{array}{c}\text { Price } \\
\text { (Tk./kg) }\end{array}$} & \multicolumn{6}{|c|}{ Milk Replacer } \\
\hline & & \multicolumn{2}{|c|}{ Wheat based $\left(T_{1}\right)$} & \multicolumn{2}{|c|}{ Shoti based $\left(\mathrm{T}_{2}\right)$} & \multicolumn{2}{|c|}{ Soybean based $\left(\mathrm{T}_{3}\right)$} \\
\hline & & $\%$ used & Cost (Tk.) & $\%$ used & Cost (Tk.) & $\%$ used & Cost (Tk.) \\
\hline Whole milk & 50.00 & - & - & - & - & - & - \\
\hline $\begin{array}{l}\text { Shoti powder (cost included } \\
\text { collection, processing \& } \\
\text { grinding etc.) }\end{array}$ & 140.00 & - & - & 39 & 54.60 & - & - \\
\hline Wheat flour & 36.00 & 29 & 10.44 & - & - & - & - \\
\hline Soy powder & 42.00 & - & - & - & - & 8 & 3.36 \\
\hline Soybean meal & 50.00 & 47 & 23.50 & 50 & 25.00 & 43 & 21.50 \\
\hline Rice flour & 30.00 & 13 & 3.90 & - & - & 38 & 11.40 \\
\hline Soybean oil & 135.00 & 9 & 12.15 & 9 & 12.15 & 9 & 12.15 \\
\hline Dicalcium phosphate (DCP) & 80.00 & 1 & 0.80 & 1 & 0.80 & 1 & 0.80 \\
\hline Vit-min-premix & 360.00 & 0.5 & 1.80 & 0.5 & 1.80 & 0.5 & 1.80 \\
\hline Common salt & 20.00 & 0.5 & 0.10 & 0.5 & 0.10 & 0.5 & 0.10 \\
\hline $\begin{array}{l}\text { Total cost } / \mathrm{kg} \text { MR } \\
\text { preparation }\end{array}$ & - & - & 52.69 & - & 94.45 & - & 51.11 \\
\hline
\end{tabular}

MR = Milk Replacer, ${ }^{*}$ January 2011-May, 11

\section{Cost and benefit analysis of feeding experimental diets}

The total cost (including collection, processing and grinding etc.) of per $\mathrm{kg}$ wheat based $\mathrm{MR}$ $\left(\mathrm{T}_{1}\right)$, shoti based MR $\left(\mathrm{T}_{2}\right)$ and Soybean based MR $\left(\mathrm{T}_{3}\right)$ were Tk. 52.69, Tk. 94.45 and Tk. 51.11, respectively (Table 6). The processing/preparation cost per kg MR was increased Tk. 41.0043.00 in $T_{2}$ group than that of $T_{1}$ and $T_{3}$ groups. The feeding cost per calf per day was reduced Tk. 88.93.00 Tk. 57.87 and Tk. 82.55 in $\mathrm{T}_{1}, \mathrm{~T}_{2}$ and $\mathrm{T}_{3}$, respectively than that of $\mathrm{T}_{0}$ group (Table 7). Results considering for both FCR and per day feeding cost, it indicates that $T_{2}$ and $T_{3}$ diets i.e, shoti and soybean based MR were effectively maintained growth of calves compared to milk fed calves. This findings is supported by the results reported earlier (Roy et al., 2011; Morel, 2000 and Skrzypek et al., 2003). 
Table 7. Feeding cost of calves (Tk/day)

\begin{tabular}{|c|c|c|c|c|}
\hline \multirow[t]{2}{*}{ Items } & \multicolumn{4}{|c|}{ Experimental diets } \\
\hline & $\mathbf{T}_{\mathbf{0}}$ & $\mathbf{T}_{1}$ & $\mathbf{T}_{2}$ & $\mathbf{T}_{3}$ \\
\hline Milk Fed & 99.65 & - & - & - \\
\hline Milk sucked & 39.65 & 39.33 & 60.65 & 43.60 \\
\hline Milk Replacer powder & - & 12.26 & 22.23 & 14.11 \\
\hline Concentrate mixture & 4.16 & 3.39 & 3.09 & 3.64 \\
\hline Green grass & 0.37 & 0.23 & 0.29 & 0.23 \\
\hline Fuel (Gas) for heating & 2.08 & 2.08 & 2.08 & 2.08 \\
\hline Medicine & 0.70 & 0.70 & 0.70 & 0.70 \\
\hline Miscellaneous & 0.50 & 0.50 & 0.50 & 0.50 \\
\hline Total cost (Tk./day/calf) & 147.42 & 58.49 & 89.55 & 64.87 \\
\hline $\begin{array}{l}\text { Feeding cost } \quad(\mathrm{Tk} . / \mathrm{d} / \mathrm{calf} ; \\
\text { excluding cost of milk sucked) }\end{array}$ & 107.77 & 19.16 & 28.90 & 21.27 \\
\hline
\end{tabular}

\section{Conclusion}

Considering the results in relation to FCR and per day feeding cost, it indicates that $T_{2}$ and $T_{3}$ diets i.e. shoti and soybean based MR were effectively maintained growth of calves compared to wheat based MR and milk fed calves. Therefore, this formulation of milk replacer can be suggested to smallholder farms as well as commercial dairy farm or feed industry for commercial MR production.

References
AOAC. 2005. Official Method of Analysis (14 ${ }^{\text {th }}$ edition). Association of Official Analytical Chemist, Arlington. Verginia 22209, USA.

Carpenter, K.J. 1951. The relative nutrition values of animal and vegetable proteins for animals. Br. J. Nutr., 5: (3) 153.

Ghorbani, G.R., Kowsar, R., Alikhani, M. and Nikkhah, A. 2007. Soymilk as a Novel Milk Replacer to stimulate early calf starter intake and reduce weaning age and costs. J. Dairy Sci., 90(12): 5692-5697.

Goering, H.K. and Van Soest, P.J. 1970. Forage fibre analysis (Apparatus, Reagents, Procedures, and Some Applications). Agric. Handbook No. 379. ARS-USDA, Washington, DC. 
Heinrichs, A.J., Losinger, W.C. and wells, S.J. 1995. Dairy calf milk replacer usage in the United States. J. Dairy Sci., 78: 2831.

Khan, R., Ghufranullah, Ahmad, S., Khan, B.D., Iqbal, M., Farid, P.K. and Hayazuddin. 2012. Effect of Milk Replacer on Performance Parameters of Different Bovine Breeds. Pakistan J. Nutr., 11 (12): 1190-1193, 2012

Mete, Y., Sadrettin, Y., Ugur, Z., Yanar, M., Yuksel, S. and Zulkadir, U. 2000. Replacement of whole milk by milk replacer in the ration of Holstein-Friesian calves raised in Eastern Turkey. Indian J. Anim. Sci., 70(9): 977.

Morel, I. 2000. Cereals instead of milk substitute in the diet of the calves. Rev. Suisse d' Agric., $32: 1,43$.

Plaza, J. and Fernandez, E. 1994. Effect of whole milk substitution by a milk replacer (MR) on calf performance. Cuban J. Agric. Sci., 28(1): 49.

Rahman, F., Rahman, M.S., Wadud, A. and Imam Hussain, S.M. 1988. Study on growth performance of baby calves as influenced by milk replacers. Bangladesh J. Agril. Sci., 15(1):189-192.

Ranjhan, S.K. and Pathak, N.N. 1979. Management and feeding of buffaloes. Vikas Publ. House. New Delhi.

Roy, A., Amanullah, S.M. and Huque, K.S. 2010. Development of milk replacer and calf starter. Proceedings of the Anuual Research Review Workshop, BLRI, Savar, Dhaka-1341.

Roy, A., Sarker, N.R., Huque, K.S. and Roy, B.K. 2011. Effect of feeding shoti based milk replacer to calves under on-farm and on-station conditions. Bang. J. Livs. Res., 18(1 \&2): 26-34.

Sajko, J., Skorko, S. H., Tywonczuk, J., Zuraw, J. and Chojnowski, W. 1998. Efficiency of milk replacer containing soycomil $\mathrm{K}$ in calf feeding. Acta. Acad. Agric. Tech. Olstenensis, Zootechnica, No. 48: 45.

Sarker, N.R., Huque, K.S. and Khaleduzzaman, A.B.M. 2012. Feeds, Fodder and Feeding Challenges for Bangladesh. Animal Husbandry Education and Profession in BangladeshA Journy of 50 years. Bangadesh Animal Husbandry Association. Farmgate, Dhaka1215.

Skrzypek, R., Osieglowski, S., Hofmanski, D., Grzymislawska, M. and Grzymislawski, S. 2003. Biological and economic evaluation of milk replacers for calve. Am. Anim. Sci., $3(1): 127$.

SPSS. 2002. Statistical Package for Social Science. Copyright (e) SPSS Inc. USA.

Steel, R.G. and Torrie, J.E. 1980. Principles and procedures of statistics. McGraw Hill Book, New York.

Tareque, A.M.M. and Chowdhury, S.M.Z.H. 2010. Agricultural Research Priority: Vision- 2030 and beyond. Bangladesh Agricultural Research Council Farmgate, Dhaka.

Vermeire, A. D. 2005. SWGP has potentially use in milk replacers. Feedstuff. 77: 28, 2005.

Wadud, A., Zaman, M.M., Samad, M.A. and Imam Hussain, S. M. 1985. Effect of whole milk and different milk replacers in calf raising. Bang. J. Anim. Sci., 14(1 \& 2): 13-17. 